\title{
KOMPETENSI PEDAGOGIK SEBAGAI INDIKATOR GURU PROFESIONAL
}

\author{
Oleh \\ Ni Nyoman Perni \\ nyomanperni80@gmail.com \\ Institut Hindu Dharma Negeri Denpasar, Indonesia
}

diterima 8 Agustus 2019, direvisi 15 September 2019, diterbitkan 1 Oktober 2019

\begin{abstract}
Pedagogic is a science that discusses education, namely the science of children's education. So pedagogic tries to explain the intricacies of children's education, pedagogic is a theory of children's education. Pedagogic as a science is really needed by teachers, especially kindergarten teachers and elementary school teachers because they will be dealing with minors. The task of the teacher is not just teaching to convey, or transform knowledge to children in school, but the teacher carries the task of developing the personality of his students in an integrated manner. The teacher develops the child's mental attitude, develops the child's conscience or child's conscience, so that the child will be sensitive to human problems, human dignity, so does the teacher only develop the child's life skills in the community so that he is able to face all the problems of his life. it discusses the notion of teacher competency, pedagogic understanding, pedagogical competence.
\end{abstract}

Key word: pedagogic competention; profesional teacher

Abstrak

Pedagogik merupakan ilmu yang membahas pendidikan, yaitu ilmu pendidikan anak.Jadi pedagogik mencoba menjelaskan tentang seluk-beluk pendidikan anak, pedagogik merupakan teori pendidikan anak. Pedagogik sebagai ilmu sangat dibutuhkan oleh guru khususnya guru taman kanak-kanak dan guru sekolah dasar karena mereka akan berhadapan dengan anak yang belum dewasa. Tugas guru bukan hanya mengajar untuk menyampaikan,atau mentransformasikan pengetahuan kepada para anak di sekolah melainkan guru mengemban tugas untuk mengembangkan kepribadian anak didiknya secara terpadu. Guru mengembangkan sikap mental anak, mengembangkan hati nurani anak atau kata hati anak, sehingga anak akan sensitive terhadap masalah-masalah kemanusiaan, harkat derajat manusia, begitu juga guru hanya mengembangkan keterampilan anak keterampilan hidup di masyarakat sehingga ia mampu untuk menghadapi segala permasalahan hidupnya.artikel ini membahas pengertian kompetensi guru, pengertian pedagogik, kompetensi pedagogic.

Kata kunci: Kompetensi Paedagogie, guru profesional 


\section{PENDAHULUAN}

Lapangan pendidikan merupakan wilayah yang sangat luas.Ruang lingkupnya mencakup seluruh pengalaman dan pemikiran manusia tentang pendidikan.Setiap orang pernah mendengar tentang perkataan pendidikan, dan setiap orang waktu kecilnya pernah mengalami pendidikan, atau setiap orang sebagai orang tua, guru, telah melaksanakan pendidikan. Namun tidak setiap orang mengerti dalam arti yang sebenarnya apa pendidikan itu dan tidak setiap orang mengalami pendidikan atau menjalankan pendidikan sebagaiman mestinya. Karena itu untuk memahami seluk beluk pendidikan kta perlu mempelajari ilmu pendidikan.

Pedagogik merupakan ilmu yang membahas pendidikan, yaitu ilmu pendidikan anak.Jadi pedagogik mencoba menjelaskan tentang selukbeluk pendidikan anak, pedagogik merupakan teori pendidikan anak. Pedagogik sebagai ilmu sangat dibutuhkan oleh guru khususnya guru taman kanak-kanak dan guru sekolah dasar karena mereka akan berhadapan dengan anak yang belum dewasa. Tugas guru bukan hanya mengajar untuk menyampaikan,atau mentransformasikan pengetahuan kepada para anak di sekolah melainkan guru mengemban tugas untuk mengembangkan kepribadian anak didiknya secara terpadu. Guru mengembangkan sikap mental anak, mengembangkan hati nurani anak atau kata hati anak, sehingga anak akan sensitive terhadap masalahmasalah kemanusiaan, harkat derajat manusia, Begitu juga guru hanya mengembangkan keterampilan anak keterampilan hidup di masyarakat sehingga ia mampu untuk menghadapi segala permasalahan hidupnya.

Guru adalah orang yang memberikan suatu ilmu atau kepandaian tertentu kepada seseorang atau sekelompok orang. Maka, untuk menjadi seorang guru harus memiliki keahlian khusus, pengetahuan, kemampuan, dan dituntut untuk dapat melaksanakan peranannya secara profesional yang dalam tugasnya guru tidak hanya mengajar, melatih tapi juga mendidik.Untuk dapat melaksanakan perannya tersebut guru harus mempunyai empat kompetensi dasar (kompetensi pedagogik, kompetensi profesional, kompetensi kepribadian, dan kompetensi sosial) sebagai modal dasar dalam mengemban tugas dan kewajibannya. Dalam makalah ini akan dibahas lebih lanjut mengenai kompetensi pedagogik.

\section{PEMBAHASAN}

\subsection{Kompetensi Paedagogik}

Kompetensi menurut Undang-undang Guru dan Dosen adalah "seperangkat pengetahuan, keterampilan, dan perilaku yang harus dimiliki, dihayati, dan dikuasai oleh guru atau dosen dalam melaksanakan tugas keprofesionalan".

- Sementara itu, menurut Kepmendiknas 045/U/2002 adalah seperangkat tindakan cerdas, penuh tanggung jawab yang dimiliki seseorang sebagai syarat untuk dianggap mampu oleh masyarakat dalam melaksanakan tugas-tugas 
dibidang pekerjaan tertentu. Lebih lanjut Gordon dan Mulyasa, (2005) merinci beberapa aspek yang ada dalam konsep kompetensi yakni:

1. Pengetahuan (Knowledge) (2) Pemahaman (Understanding)

(3) Minat (Interest

Kemampuan (Skill) (5) Nilai (6) Sikap

Jadi, kompetensi guru dapat dimaknai sebagai kebulatan pengetahuan, keterampilan dan sikap yang berwujud tindakan cerdas dan penuh tanggung jawab dalam melaksanakan tugas sebagai agen pembelajaran. Sedangkan Pedagogik merupakan suatu kajian tentang pendidikan anak, berasal dari kata Yunani "paedos", yang berarti anak laki-laki, dan "agogos" artinya mengantar, membimbing. Jadi pedagogik secara harfiah berarti pembantu anak laki-laki pada zaman Yunani kuno yang pekerjaannya mengantarkan anak majikannya ke sekolah.Kemudian, secara kiasan pedagogik ialah seorang ahli yang membimbing anak ke arah tujuan hidup tertentu. Menurut Prof. Dr. J. Hoogveld (Belanda) pedagogic adalah ilmu yang mempelajari amsalah membimbing anak ke arah tujuan tertentu, yaitu supaya ia kelak "mampu secara mandiri menyelesaikan tugas hidupnya". Jadi pedagogik adalah ilmu mendidik anak. Makhluk pedagogik adalah manusia yang dilahirkan membawa potensi dapat dididik dan dapat mendidik. Manusia sebagai mahluk dengan tingkat kecerdasan yang tinggi, memang masih membutuhkan bimbingan dan didikan sehingga dapat menjadi manusia yang lebih baik lagi kedepannya, karena setiap manusia memiliki potensi untuk berkembang menjadi lebih baik dan lebih cerdas Meskipun demikian, jika potensi itu tidak dikembangkan niscaya ia akan kurang bermakna dalam kehidupan. Dengan pendidikan dan pengajaran potensi itu dapat dikembangkan.Kewajiban mengembangkan potensi itu merupakan beban dan tanggungjawab orang tua dan pendidik secara umum.

Menurut

Peraturan Pemerintah (PP) Nomor 19 Tahun 2005 tentang Standar Nasional Pendidikan, menyebutkan ada empat kompetensi guru yaitu kompetensi pedagogik, kompetensi kepribadian, kompetensi profesional, dan kompetensi sosial. Yang dimaksud dengan kompetensi pedagogik adalah kemampuan mengelola pembelajaran peserta didik yang meliputi pemahaman terhadap peserta didik, perancangan dan pelaksanaan pembelajaran, evaluasi hasil belajar, dan pengembangan peserta didik untuk mengaktualisasikan berbagai potensi yang dimilikinya.

Dalam Standar Nasional Pendidikkan, penjelasan Pasal 28 ayat (3) butir a dikemukakan bahwa kompetensi pedagogik adalah kemampuan mengelola pembelajaran peserta didik yang meliputi pemahaman terhadap peserta didik, perancangan dan pelaksanaan pembelajaran, evaluasi hasil belajar, dan pengembangan peserta didik untuk mengaktualisasikan berbagai potensi yang dimilikinya. Kompetensi pedagogik merupakan kemampuan guru dalam pengelelolaan pembelajaran peserta didik, meliputi: 
1. Pemahaman wawasan atau landasan pendidikan

2. Pemahaman terhadap peserta didik

3. Pengembangan kurikulum/silabus

4. Perancangan pembelajaran

5. Pelaksanaan pembelajaran yang mendidik dan dialogis

6. Pemanfaatan teknologi pembelajaran

7. Evaluasi hasil belajar (EHB)

8. Pengembangan peserta didik untuk mengaktualisasikan berbagai potensi yang dimilikinya.

Secara operasional, kemampuan mengelola pembelajaran menyangkut tiga fungsi manajerial, yaitu perencanaan, pelaksanaan, dan pengendalian. Agar proses pembelajaran dapat dilaksanakan secara efektif dan efisien, serta mencapai hasil yang diharapkan, diperlukan kegiatan manajemen sistem pembelajaran, sebagai keseluruhan proses untuk melaksanakan kegiatan pembelajaran secara efektif dan efisien.

Guru

diharapkan membimbing dan mengarahkan pengembangan kurikulum dan pembelajaran secara efektif, serta melakukan pengawasan dalam pelaksanaannya. Guru merupakan seorang manajer dalam pembelajaran,

bertanggungjawab yang perencanaan, pelaksanaan, dan penilaian perubahan atau perbaikan program pembelajaran. Untuk kepentingan tersebut, sedikitnya terdapat empat langkah yang harus dilakukan, yakni menilai kesesuaian program yang ada dengan tuntutan kebudayaan dan kebutuhan peserta didik, meningkatkan perencanaan program, memilih dan melaksanakan program, serta menilai perubahan program.

Pemahaman terhadap peserta didik merupakan salah satu kompetensi pedagogik yang harus dimiliki guru.Sedikitnya terdapat empat hal yang harus dipahami guru dari peserta didiknya, yaitu tingkat kecerdasan, kreativitas, cacat fisik dan perkembangan kognitif.

Memahami karakteristik individu dalam pembelajaran peserta didik diklasifikasikan ke dalam tiga kelompok yaitu normal, sedang, dan tinggi. Pembelajaran yang didiversifikasi untuk masing-masing kelompok mempunyai tujuan sebagai berikut:

1. Kelompok Normal

- Mengembangkan pemahaman tentang prinsip dan praktik aplikasi dan mengembangkan kemampuan praktik akademik yang berhubungan dengan pekerjaan

2. Kelompok Sedang

- Mengembangkan kemahiran berkomunikasi, kemahiran menggali potensi diri, dan aplikasi praktikal

- Mengembangkan kemahiran akademik dan kemahiran praktikal sehubungan dengan tuntutan dunia kerja maupun untuk melanjutkan program pendidikan professional 
3. Kelompok Tinggi

- Mengembangkan pemahaman tentang prinsip, teori, dan aplikasi

- Mengembangkan kemampuan akademik untuk memasuki pendidikan tinggi

Perancangan pembelajaran merupakan salah satu kompetensi pedagogis yang harus dimiliki guru, yang akan bermuara pada pelaksanaan pembelajaran. Perancangan pembelajaran sedikitnya mencakup tiga kegiatan yaitu identifikasi kebutuhan, perumusan kompetensi dasar, dan penyusunan program pembelajaran.

Kegagalan pelaksanaan
pembelajaran sebagian besar
disebabkan oleh penerapan metode
pendidikan konvensional, anti dialog
proses penjinakan, pewarisan
pengetahuan, dan tidak bersumber
pada realitas masyarakat.
Sehubungan dengan hal itu, salah satu kompetensi pedagogik yang harus dimiliki guru seperti dirumuskan dalam SNP berkaitan dengan pelaksanaan pembelajaran.Hal tersebut ditegaskan kembali dalam Rencana Peraturan Pemerintah tentang guru, bahwa guru harus memiliki kompetensi untuk melaksanakan pembelajaran yang mendidik dan dialogis. Hal ini berarti bahwa pelaksanaan pembelajaran harus berangkat dari proses dialogis antar sesame subjek pembelajaran, sehingga melahirkan pemikiran kritis dan komunikasi. Tanpa ada komunikasi tidak akan ada pendidikan sejati.

Dalam pembelajaran, tugas guru yang paling utama adalah mengkondisikan lingkungan agar menunjang terjadinya perubahan perilaku dan pembetukan kompetensi peserta didik.Umumnya pelaksanaan pembelajaran mencakup tiga hal yaitu pre test, proses, dan post test.

Penggunaan teknologi dalam pendidikan dan pembelajaran (elearning) dimaksudkan untuk memudahkan atau mengefektifkan kegiatan pembelajaran.Dalam hal ini guru dituntut untuk memiliki kemampuan menggunakan media dan mempersiapkan materi pembelajaran dalam suatu sisten jaringan computer dalam suatu sistem jaringan komputer yang dapat diakses oleh peserta didik.

$$
\text { Evaluasi hasil belajar }
$$

digunakan untuk mengetahui perubahan perilaku dan pembentukan kompetensi peserta didik, yang dapat dilakukan dengan penilaian kelas,tes kemampuan dasar, penilaian akhir satuan pendidikan dan sertifikasi, bencharmarking, serta penilaian program.

Pengembangan peserta didik merupakan bagian dari kompetensi pedagogik yang harus dimiliki oleh guru, untuk mengaktualisasikan berbagai potensi yang dimiliki oleh setiap peserta didik. Pengembangan peserta didik dapat dilakukan oleh guru melalui berbagai cara, antara lain melalui kegiatan ekstra kurikuler (ekskull), pengayaan dan remedial, serta bimbingan dan konseling (BK). Kompetensi pedagogik merupakan kemampuan dalam pengelolaan peserta didik meliputi :

1. Pemahaman wawasan guru akan landasan dan filsafat pendidikan

2. Guru memahami potensi dan keberagaman peserta didik 
sehingga dapat didesain strategi pelayanan belajar sesuai keunikan masingmasing peserta didik

3. Guru mampu mengembangkan kurikulum atau silabus baik dalam bentuk dokumen maupun implementasi dalam bentuk pengalaman belajar

4. Guru mampu menyusun rencana dan strategi pembelajaran berdasarkan standar kompetensi dan kompetensi dasar

5. Mampu melaksanakan pembelajaran yang mendidik dengan suasana dialogis dan interaktif

6. Mampu melakukan evaluasi hasil belajar dengan memenui prosedur dan standar yang dipersyaratkan

7. Mampu mengembangkan bakat dan minat peserta didik melalui kegiatan intrakurikuler dan ekstrakurikuler untuk mengaktualisasikan berbagai potensi yang dimilkinya.

Dengan demikian tampak bahwa kemampuan pedagogik bagi guru bukanlah hal yang sederhana, karena kualitas guru haru di atas rata-rata. Kualitas ini dapat dilihat dari aspek intelektual yang meliputi :

1. Logika sebagai pengembangan kognitif mencakup kemampuan intelektual mengenal lingkungan terdiri atas enam macam yang disusun secara hierarkis dari yang sederhana sampai yang kompleks. Yaitu :
2. Pengetahuan (kemampuan mengingat kembali hal-hal yang telah dipelajari)

3. Pemahaman (kemampuan menangkap makna atau arti sesuatu hal)

4. Penerapan (kemampuan memperguanakn hal-hal yang telah dipelajari untuk manghadapi situasi-situasi baru dan nyata)

5. Analisis (kemampuan menjabarkan sesuatu menjadi bagian-bagian sehingga struktur organisasinya dapat dipahami)

6. Etika sebagai pengembangan efektif mencakup kemampuan emosional dalam mengalami dan menghayati sesuatu hal meliputi lima macam kemampuan emosional disusun secara hierarkis, yaitu :

7. Kesadaran (kemampuan untuk memperhatikan sesuatu hal)

8. Partisipasi (kemampuan untuk turut serta atau terlibat dalam sesuatu hal)

9. Penghayatan nilai (kemampuan untuk menerima nilai dan terikat kepadanya)

10. Pengorganisasian nilai ( kemampuan untuk memiliki sistem nilai dalam dirinya)

11. Karakterisasi diri kemampuan untuk memiliki pola hidup dimana sistem nilai yang terbentuk di dalam dirinya mampu mengawasi tingkah lakunya)

12. Estetika sebagai pengembangan psikomotorik yaitu kemampuan motorik menggiatkan dan mengkoordiansikan kegiatan. 
Yaitu terdiri dari: Untuk menghadapi tantangan tersebut, guru perlu berpikir secara antisipasi dan proaktif. Guru secara terus menerus belajar sebagai upaya melakukan pembaharuan atas ilmu yang dimilikinya. Caranya dengan sering melakukan penelitian baik melalui kajian pustaka, maupun melakukan penelitian seperti penelitian tindakan kelas.

\subsection{GURU PROFESIONAL}

Menurut James M. Cooper dalam Wina Sanjaya : "A teacher is a person charged with the responsibility of helping others to learn and to behave in new and different ways."

Pengertian dari guru dalam UU No. 14 Tahun 2005, guru adalah pendidik profesional dengan tugas utama mendidik, mengajar, membimbing, mengarahkan, melatih, menilai, dan mengevaluasi peserta didik pada pendidikan anak usia dini jalur pendidikan formal, pendidikan dasar, dan pendidikan menengah. Dalam UU No. 14 Tahun 2005 tentang guru dan dosen mendefinisikan bahwa profesional adalah pekerjaan atau kegiatan yang dilakukan oleh seseorang dan menjadi sumber penghasilan kehidupan yang memerlukan keahlian, kemahiran atau kecakapan untuk memenuhi standar mutu atau norma tertentu serta memerlukan pendidikan profesi.

Menurut Dedi Supriyadi dalam Suparlan, menjelaskan secara jelas tentang pengertian profesi, profesional dan profesionalisme. Profesi menunjuk pada suatu pekerjaan atau jabatan yang menuntut suatu keahlian, tanggung jawab dan kesetiaan dalam pekerjaan itu. Profesional menunjuk dua hal, yaitu orangnya dan penampilan atau kinerja orang itu dalam melaksanakan tugas atau pekerjaannya. Seseorang dikatakan kompeten di bidang tertentu adalah sesorang yang memiliki kecakapan kerja, atau keahlian khusus yang sesuai dengan tuntutan bidang kerja yang bersangkutan.

W.R. Houston (Kuswana,WS, 1995) mengungkapkan bahwa;

"kecakapan kerja diejawantahkan dalam perbuatan yang bermakna, bernilai sosial, dan ekonomi, serta memenuhi standar (kriteria) tertentu yang diakui dan disyahkan oleh kelompok profesinya atau oleh warga masyarakat". Secara nyata orang kompeten mampu melakukan tugasnya di bidangnya secara efektif dan efisien. Kadar kompetensi tidak hanya menunjuk pada kuantitas tetapi sekaligus menunjuk pada kualitas kerja.kompetensi dapat diklasifikasikan sebagai berikut :

1. Kompetensi dasar

Kompetensi yang harus dimiliki untuk memilihara dan memenuhi kebutuhan hidupnya. Meliputi :

1. Bertakwa kepada Tuhan Yang Maha Esa

2. Berperan dalam masyarakat sebagai warga negara berjiwa pancasila

3. Mengembangkan sifatsifat terpuji yang dipersyaratkan bagi seorang guru

4. Kompetensi umum 
Kompetensi yang harus dimiliki untuk bisa hidup bersama di masyarakat, meliputi :

1. Berinteraksi dengan teman sejawat untuk meningkatkan kemampuan profesional

2. Berinteraksi dengan masyarakat

3. Kompetensi teknis/keterampilan

Kompetensi yang harus dimiliki untuk melakukan suatu pekerjaan atau kegiatan.

1. Melaksanakan bimbingan dan penyuluhan untuk siswa yang mengalami kesulitan belajar dan utnuk siswa yang memiliki kelainan (berkebuuhan khusus)

2. Melaksanakan administrasi sekolah

3. Melaksanakan penelitian sederhana untuk keperluan mengajar

4. Kompetensi profesional

2. Kompetensi profesional meliputi yaitu Menguasai landasan pendidikan, yang meliputi :

- Mengenal tujuan pendidikan untuk mencapai tujuan pendidikan nasional.

- Mengenal fungsi sekolah dalam masyarakat, sebagai pusat kebudayaan dan pendidikan.

- Mengenal prinsip psikologi pendidikan yang dapat dimanfaatkan dalam proses belajar mengajar.

\section{PENUTUP} $\begin{array}{lr}\text { Kompetensi } & \text { pedagogik } \\ \text { adalah kemampuan } & \text { mengelola } \\ \text { pembelajaran peserta } & \text { didik yang }\end{array}$ meliputi pemahaman terhadap peserta didik, perancangan dan pelaksanaan pembelajaran, evaluasi hasil belajar, dan pengembangan peserta didik untuk mengaktualisasikan berbagai potensi yang dimilikinya.

Kompetensi pedagogik merupakan kemampuan guru dalam pengelelolaan pembelajaran peserta didik, meliputi: 1). Pemahaman wawasan atau landasan pendidikan, 2). Pemahaman terhadap peserta didik, 3). Pengembangan kurikulum/silabus, 4). Perancangan pembelajaran, 5). Pelaksanaan pembelajaran yang mendidik dan dialogis, 6) Pemanfaatan teknologi pembelajaran, 7). Evaluasi hasil belajar (EHB), 8). Pengembangan peserta didik untuk mengaktualisasikan berbagai potensi yang dimilikinya.

Dengan demikian tampak bahwa kemampuan pedagogik bagi guru bukanlah hal yang sederhana, karena kualitas guru haru di atas rata-rata. Kualitas ini dapat dilihat dari aspek intelektual yang meliputi : 1) Logika, 2) Etika, 3)Estetika

Guru secara terus menerus belajar sebagai upaya melakukan pembaharuan atas ilmu yang dimilikinya, yaitu dengan cara sering melakukan penelitian baik melalui kajian pustaka, maupun melakukan penelitian seperti penelitian tindakan kelas. Sehingga guru dapat dikatakan profesional apabila dapat menjalankan tugas dan kewajibannya dengan baik. 


\section{DAFTAR PUSTAKA}

Darmadi, Hamid. 2010. Kemampuan Dasar Mengajar (Landaasan Konsep dan Implementasi). Bandung: Alfabeta

Mulyasa.2007. Standar Kompetensi dan Sertifikasi Guru. Bandung: PT Remaja Rosdakarya

PF, K. and Partini, N. (2017). The Implementation of Yoga Teaching in Improving Elementary School Students' Learning Concentration.In 2nd International Conference on Sociology Education - Volume 2: ICSE, ISBN 978-989-758316-2, pages 149-155. DOI: $10.5220 / 0007106007890795$

Roqib, Moh. 2009. Kepribadian Guru. Yogyakarta: Grafindo

Sadulloh, Uyoh. 2010. Pedagogik (Ilmu Mendidik). Bandung: Alfabeta

Sagala, Saiful.2009. Kemampuan Profesional Guru dan Tenaga
Kependidikan. Bandung Alfabeta

Suparlan. 2006. Guru Sebagai Profesi. Yogyakarta: Hikayat

Suparlan, Guru Sebagai Profesi, Yogyakarta: Hikayat, 2006, hlm. 85-86

Uyoh Sadulloh, Pedagogik (Ilmu Mendidik), Bandung: Alfabeta, 2010, hlm. 2

Moh Roqib, Kepribadian Guru, Yogyakarta: Grafindo, 2009, hlm. 119

Hamid Darmadi, Kemampuan Dasar Mengajar (Landaasan Konsep dan Implementasi), Bandung: Alfabeta, 2010, hlm. 31

Mulyasa, Standar Kompetensi dan Sertifikasi Guru, Bandung: PT Remaja Rosdakarya, 2007, hlm. 75-113

Saiful Sagala, Kemampuan Profesional Guru dan Tenaga Kependidika,. Bandung Alfabeta, 2009, hlm. 46 